\title{
Integrated Solution to the Problem of Resource-Saving Fixing of Moving Sands
}

\author{
Makhamadjan Mirakhmedov* and Maujuda Muzaffarova \\ Tashkent Institute of Railway Engineering, Uzbekistan
}

Submission: February 18, 2019; Published: March 28, 2019

*Corresponding author: Makhamadjan Mirakhmedov, Tashkent Institute of Railway Engineering, Uzbekistan

\begin{abstract}
Movable sands, which occupy large areas around the world, are becoming more intensively developed, but their susceptibility to deflation causes the problem of dispersal, transfer and deposition of sands that impede the normal operation of engineering facilities. Science and practice have offered many solutions, but they are far from perfect from the point of view of economic and environmental. A comprehensive resourcesaving solution to the problem is proposed based on: the priority of the physicochemical method of fixing and using a water-soluble binder; pre-moistening of sand, which allows significant savings in consumption of the binder and its working composition, as well as extending the production time of work and the use of material and human resources; laconization of research methods; use of waste and related products of local production, two of which are studied in this work.
\end{abstract}

Keywords: Methodology; Sandy deserts; Drifts; Protection; Sand fixation; Technological solutions; New technical method; Construction and technological parameters of protection; Physicochemical method; Technological gap; Processing strips

\section{Introduction}

Deserts and semi-deserts occupy 31.4 million $\mathrm{km}^{2}$ on the surface of the Earth, including the Sahara (covers 11 countries of North and West Africa), and Namib (South Africa, Namibia) in Africa, Rub al-Khali (Arabian Peninsula), Dashti- Naumid (Iran), Karakum and Kyzylkum (Turkmenistan, Uzbekistan, Kazakhstan, Tar (Pakistan, India), Gobi and Takla-Makan (China) in Asia, Mojave with its Death Valley in North America, the Great and Small Sandy Deserts, the Simpson Desert in Australia [1]. Building engineering communications in these conditions over the past two centuries have tended to expand. Eniyu [25] Construction sandy deserts associated with the negative impact of exogenous process - deflation and its activation brittle fracture bioravnovesiya-destruction of vegetation, which is formed very slowly [6-11]. In the Republic of Uzbekistan, mobile sands occupying more than $30 \%$ of the territory are sources of blowing and drifting irrigation networks, roads and railways, gas pipelines and, as a result, the reason for reducing the safety of their operation [12]. Therefore, in the construction and operation of engineering structures in sandy deserts, the problem of protecting them from blowing and from drifts is given significant importance [13-15].

Generalization of the Degree of Studying the Problem and the Tasks of its Solution

In a series of measures to protect against the effects of deflation, a special place belongs to methods of bringing a sandy surface to a fixed state [16]. The disadvantage of the widely used method of mechanical protection devices, especially reed cells, in addition to the weak possibility of mechanization, is that plants survive poorly (10-15\%) [17]. From this point of view, a physicochemical method for obtaining a protective crust using binders is promising [18-22]. The possibility of their use for the formation of protective bark is estimated by their antideflationary stability [23]. Despite this, the fixation of mobile sands by various methods, including the physicochemical method based on binders, remains economically and sometimes ecologically impractical [24]. In this regard, it is important to improve the existing and develop new technological solutions for the physicochemical method based on the impregnation of mobile sand [25].

The following are some of the technological solutions used in this study:

A. the use of multicomponent binders and emulsions is not technological and requires pre-heating and preparation in a special installation. These circumstances lead to higher prices and higher labor costs;

B. many binders are imported. For example, in Uzbekistan, with the exception of gossypol resin and bitumen, other binders are not produced [27];

C. all recommended binders are used a priori in the dry period of the year, despite the fact that emulsions and 


\section{Civil Engineering Research Journal}

especially water-soluble binders freely penetrate wet sand. Impregnation in dry sand limits the time of work and, as a result, the use of resources during the year;

D. to assess the stability of the astringent-sandy crust, a variety of physicomechanical characteristics and parameters are used, the determination of which requires a considerable amount of time and money.

\section{Methodological Approach to the Complex Solution of the Problem}

The present studies in the methodological aspect allow us to systematize the disparate data as the achievement of a resourcesaving goal of solving the problem of combating the effects of deflation. Therefore, at the first stage of research, the watersoluble type of binder was determined by analyzing technical and economic indicators. Further decline costs associated primarily with the pyrimeneniem waste and by-products of local production. It should be noted that to prove the possibility of using a binder, it is necessary to conduct a large number of experimental studies. Therefore, there was a question about the rational limitation, at the first stage of the study, the number of structural-mechanical characteristics for saving resources. From the analysis of literature and regulatory sources, the requirements for anti-deflationary protective coatings were established: E1<8x106 Pa, fast elastic deformation modulus, E2 $<1.1 \times 106 \mathrm{~Pa}$, slow elastic deformation modulus, E<4.4 x106 $\mathrm{Pa}$, elastic equilibrium modulus, maximum plastic viscosity $\eta>1.05 \times 106 \mathrm{~Pa}, \mathrm{~s}$, elasticity $(\lambda)$, static plasticity, and a period of true plastic relaxation with a shear strain. Simulation in a wind tunnel found that all these characteristics can be summarized in two parameters: crust thickness and plastic strength, which allows us to develop a resource-saving research method for the first stage of justifying the possibility of using a binder. Upon receipt of positive results further in-depth studies are conducted.

The sharp decrease in the rate of impregnation prompted the idea that perhaps the nature of the impregnation changes from predominantly gravitational to predominantly capillary. This made it possible to put forward a working hypothesis and confirm experimentally that when wet sand is impregnated, a film of moisture is formed on the sand, the volume and size of the active pores in which the working composition of the binder, forming a crust, moves decreases. The efficiency of phytomelioration directly depends on the retention of moisture under the crust for a long time. To create a reserve of moisture under a protective crust, it is obvious that splashing of sand binder onto the surface should be done after rain, and to prolong the work, after the preliminary artificial moistening of the sandy surface. Thus, the proposed method of fixing sand consists of the following methods: spraying; creation of protective diffusion crust by impregnation of sand with a working binder composition. Thus, in order to obtain a protective bindery sand crust, a new technological solution was developed by the complex use of interrelated theoretical and experimental methods for studying initial materials; physical modeling of experiments; modern and classic measuring instruments; graphical interpretation of the results; X-ray and spectroscopic analysis; mathematical statistical method.

\section{Methods and Means of Experimental Research and Analysis of the Received Results}

In the experiments, the sand of the Southern Kyzylkum was used, taken from the right track of the Navoi-Uchkuduk railway line. The granulometric composition and structural-mechanical characteristics of the sands were determined by the standard method. It is established that sand has a modulus equal to 1 .

The mineralogical composition of Kyzylkum sand was studied on a PANalytical diffractometer and under an MBS-2 binocular microscope. Sand consists of quartz-60-63\%, albites-25-26\%; calcite-7-9\%, amphiboles $-2 \%$; biotite and others $-0.2-0.6 \%$. The chemical composition of the binder materials (dextrin and KP-001 glue) was studied on a Nicolet iS50 FT-IR spectrometer. In conducting experiments on the impregnation of dry and wet sand, the method of mathematical planning was used. The physicomechanical characteristics of the resulting knitted sandy crusts and the change in their values were measured by AIP-1-3 according to GOST 23750-79 (imitation of operating conditions). The depth of impregnation of the binder in the sand was determined using a moisture meter with a probe installed at a depth of $100 \mathrm{~mm}$. The plastic strength of the astringent crust was determined on a conical plastometer of the University of Moskow (MSU) system.

Sand humidity was measured with an inductive universal moisture meter with a parallel measurement of air temperature using a GM816 digital anemometer-thermometer. In the experiments, the sand of the Southern Kyzylkum was used, taken from the right track of the Navoi-Uchkuduk railway line. The granulometric composition and structural-mechanical characteristics of the sands were determined by the standard method. It is established that sand has a modulus equal to 1 . The mineralogical composition of Kyzylkum sand was studied on a PANalytical diffractometer and under an MBS-2 binocular microscope. Sand consists of quartz -60-63\%, albites - 25-26\%; calcite $-7-9 \%$, amphiboles $-2 \%$; biotite and others $-0.2-0.6 \%$. The chemical composition of the binder materials (dextrin and KP-001 glue) was studied on a Nicolet iS50 FT-IR spectrometer. In conducting experiments on the impregnation of dry and wet sand, the method of mathematical planning was used.

The physicomechanical characteristics of the resulting knitted sandy crusts and the change in their values were measured by AIP-1-3 according to GOST 23750-79 (imitation of operating conditions). The depth of impregnation of the binder in the sand was determined using a moisture meter with a probe installed at a depth of $100 \mathrm{~mm}$. The plastic strength of the astringent crust was determined on a conical plastometer 
of the University of Moskow (MGU) system. Sand humidity was measured with an inductive universal moisture meter with a parallel measurement of air temperature using a GM816 digital anemometer-thermometer (Figure 1).

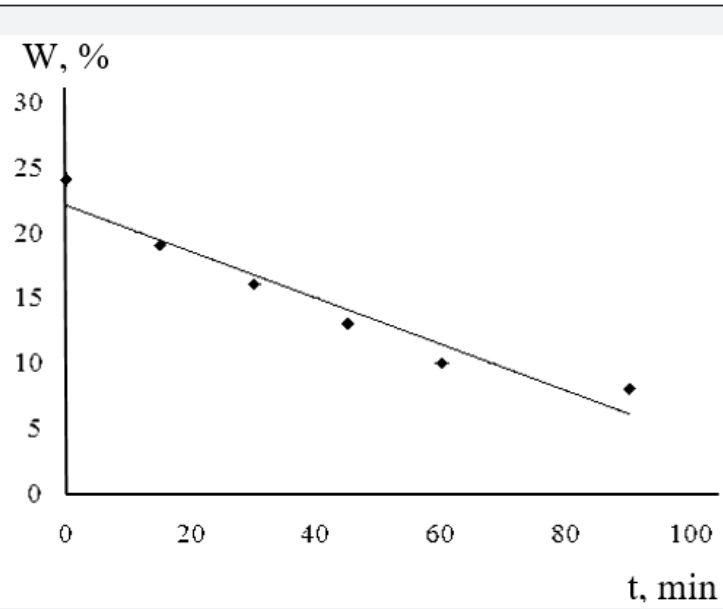

Figure 1: Change in sand moisture over time.

The obtained dependence with the reliability of approximation $\mathrm{R}^{2}=0.94$ is described by the formula:

$$
W=22.08-0,18 * t
$$

Using this dependence and knowing the limiting humidity, the time of possible start of impregnation after moistening was determined, which was 10 - 15 minutes. To identify the results of laboratory studies, it was necessary to ensure compliance with the experimental conditions and natural conditions. Considering the instability of air temperature, it was first of all necessary to determine the temperature regime of the tests. The average daily temperature was found, corresponding to the time of sanding works from 9 to 18 hours. For this purpose, a statistical analysis was carried out of the average monthly daily variation of air temperature over the past 30 years at 14 meteorological stations located in the region of sandy deserts, where the potential danger of sand deflation is observed. As a result, the interval of the average monthly temperature variation was found to be $30 \pm 2$. Features of the formation of the structure of protective crusts on dry and wet sands were studied by X-ray diffraction analysis (Empyreen diffractometer) and IR spectroscopy (Nicolet iS50 FT-IR spectrometer from Thermo Scientific (USA)). To optimize the concentration of binders in the first stage, the dependence of the depth of impregnation of the binder on the concentration of the solution was investigated. It was found that the required crust thickness $\mathrm{h} \geq 5 \mathrm{~mm}$ can be obtained at a concentration of the binder solution of not more than $8 \%$. Further studies were conducted to determine the impregnability of sand of different humidity and the detection of the threshold humidity (Table 1).

Table 1: The main parameters of wind resistance of the protective layer of $2.2 \%$ dextrin solution.

\begin{tabular}{|c|c|c|c|c|c|c|}
\hline \multirow{2}{*}{$\begin{array}{l}\text { Binder Con- } \\
\text { sumption } q \text {, } \\
\qquad 1 / \mathrm{m}^{2}\end{array}$} & \multicolumn{3}{|c|}{ On Dry Sand } & \multicolumn{3}{|c|}{ On Wet Sand } \\
\hline & $\begin{array}{c}\text { Peel Thickness, } \\
\text { h, mm }\end{array}$ & $\begin{array}{c}\text { Plastic } \\
\text { Strength, } \mathrm{P}, \mathbf{\kappa} \mathrm{Pa}\end{array}$ & $\begin{array}{l}\text { Weight Loss Samples, } \\
\qquad \Delta \mathrm{m}, \%\end{array}$ & $\begin{array}{c}\text { Peel Thickness, } \\
\text { h, mm }\end{array}$ & $\begin{array}{c}\text { Plastic } \\
\text { Strength, Р, кРa }\end{array}$ & $\begin{array}{l}\text { Weight Loss Samples, } \\
\qquad \Delta \mathrm{m}, \%\end{array}$ \\
\hline 3 & $5-9$ & $3,5-4$ & 0,7 & 15 & $3,5-4,5$ & 0,3 \\
\hline 2 & $5-7$ & $3,3-3,5$ & $3-5$ & $10-13$ & $3,5-4,0$ & 0,5 \\
\hline 1,5 & $3-5$ & $3-3,2$ & 15 & $8-11$ & $3-3,6$ & $1-3$ \\
\hline 1,0 & 3 & $2,7-3$ & 20 & $5-6$ & $2,7-3,2$ & $3-5$ \\
\hline 0,5 & $0-2$ & - & - & $3-4$ & $2,3-2,8$ & 10 \\
\hline
\end{tabular}

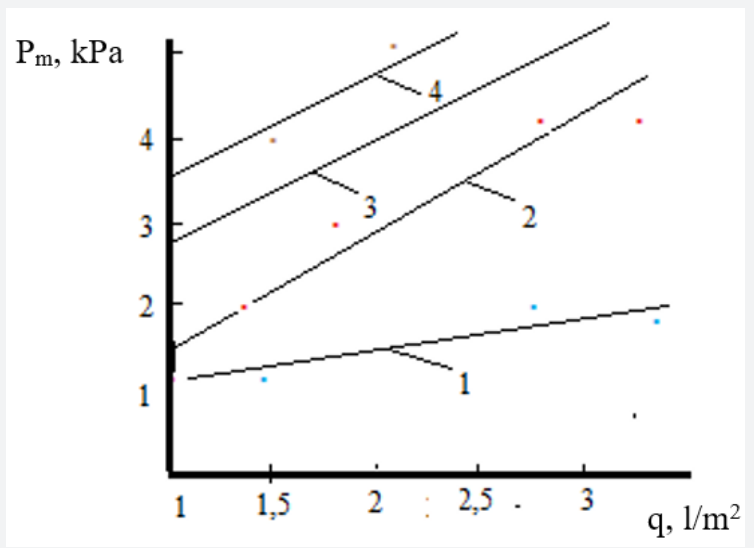

Figure 2: Dependence of plastic strength $P_{m}$ on consumption q and concentration $C$ of dextrin solution (air-dry sand).
$1,2,3,4$ - protective crusts, obtained from 1.5, respectively; $2,5,8 \%$ solutions of dextrin; 5 -the line of maximum required value of plastic strength.

The research results of the proposed new binders have shown that impregnation begins at a moisture content of less than $22 \%$, however, the formation of the required thickness is possible starting from a moisture content of $20-21 \%$. The time of the possible beginning of the process of sand impregnation after it was moistened, a change in the moisture content of a layer of sand $5 \mathrm{~mm}$ thick with time was studied (Figure 2) (Table 2).

In order to study the mutual connection of the impregnation with the average daily temperature course, experiments were performed on the impregnation of sand with binding solutions at different times of the day on dry and wet sand. As a result, it was found that the time of day at which the impregnation is carried out has virtually no effect on the parameters of the 


\section{Civil Engineering Research Journal}

protective peel under study. Protective crusts obtained in the laboratory were tested for wind resistance in a wind tunnel with compliance with the similarity criteria (geometric, Froude, etc.).
Wind resistance was estimated by weight loss of the samples. For wind-resistant crusts, their plastic strength was determined (Table1).

Table 2: Determination of the moisture limit for the technological feasibility of the method impregnation (consumption $1.5 \mathrm{l} / \mathrm{m} 2$ ).

\begin{tabular}{|c|c|c|c|c|c|}
\hline \multirow{2}{*}{ Type of solution } & \multirow{2}{*}{ Sand moisture, $\mathrm{W}, \%$} & \multicolumn{3}{|c|}{ Peel thickness $\mathrm{h}, \mathrm{mm}$ at a solution consumption, $1 / \mathrm{m}^{2}$} & \multirow{2}{*}{ Impregnability } \\
\hline & & 3 & 2 & 1,5 & \\
\hline \multirow{4}{*}{ Dextrin $(2,2 \%)$} & 24 & - & - & - & No impregnation \\
\hline & 22 & До 5 & До 3 & До 3 & Partial impregnation \\
\hline & 20 & $15-20$ & Oct-15 & 08-Nov & Fully impregnated \\
\hline & 19 & $15-18$ & Oct-13 & 08-Oct & Fully impregnated \\
\hline \multirow{4}{*}{$\begin{array}{l}\text { Polyacrylamide } \\
\text { glue }(1,5 \%)\end{array}$} & 24 & - & - & - & No impregnation \\
\hline & 22 & До 5 & До 3 & До 3 & Partial impregnation \\
\hline & 20 & $15-22$ & Nov-16 & 10-Dec & Fully impregnated \\
\hline & 19 & $15-19$ & Oct-15 & 09-Nov & Fully impregnated \\
\hline
\end{tabular}

As shown by the results of the experiments, with equal consumption of the binder, the protective crust on wet sand as compared to the crust obtained on dry sand after purging has less weight loss. The thickness of the crust on wet sand wears out 2-7 times less. The protective crusts obtained on dry sand with a binder consumption of at least $1.5 \mathrm{l} / \mathrm{m}^{2}$ proved to be resistant to wind load; on wet sand, the crust resistance was observed at a lower consumption $-0.5 \mathrm{l} / \mathrm{m}^{2}$, probably due to an increase in crust by reducing the pore space of the sandy substrate. Considering that deserts with moving sands belong in relief to the plains with slight inclines (within the location of railways and roads), studies have shown that the plastic strength of the crust on slopes 5-100 must be at least $5 \mathrm{kPa}$ ( Table 3).

Table 3: The main parameters of wind resistance of the protective layer of $1.5 \%$ solution of polymer adhesive KP-001.

\begin{tabular}{|c|c|c|c|c|c|c|}
\hline \multirow{2}{*}{$\begin{array}{c}\text { Binder Con- } \\
\text { sumption q, } \\
\mathbf{1} \mathbf{m}^{\mathbf{2}}\end{array}$} & \multicolumn{3}{|c|}{ On Dry Sand } & \multicolumn{3}{c|}{ On Wet Sand } \\
\cline { 2 - 7 } & $\begin{array}{c}\text { Peel Thickness, } \\
\mathbf{h}, \mathbf{m m}\end{array}$ & $\begin{array}{c}\text { Plastic Strength, } \\
\mathbf{P}, \mathrm{KPa}\end{array}$ & $\begin{array}{c}\text { Weight loss Samples, } \\
\Delta \mathbf{m}, \mathbf{\%}\end{array}$ & $\begin{array}{c}\text { Peel Thickness, } \\
\mathbf{h}, \mathbf{m m}\end{array}$ & $\begin{array}{c}\text { Plastic Strength, } \\
\mathbf{P}, \mathrm{KPa}\end{array}$ & $\begin{array}{c}\text { Weight Loss Samples, } \\
\Delta \mathbf{m}, \mathbf{\%}\end{array}$ \\
\hline 3 & $5-10$ & $3,5-4,5$ & 0,7 & $15-20$ & $5-8$ & 0,3 \\
\hline 2 & $3-5$ & $3,3-3,5$ & $3-5$ & $10-15$ & $3,5-4,0$ & 0,5 \\
\hline 1,5 & 3 & $3-3,2$ & 20 & $10-12$ & $3-3,6$ & $1-3$ \\
\hline 1,0 & 2 & 2,5 & 20 & $5-10$ & $2,7-3,2$ & $3-5$ \\
\hline 0,5 & $0-1$ & - & - & $3-5$ & $2,3-2,8$ & 10 \\
\hline
\end{tabular}

When sands were recorded in a water-saturated state (W $=20 \%$ ), an increase in plastic strength was observed 1.5-2.0 times as compared with the strength of sands in the air-dry state. Consequently, when wet sands are fixed in the wet state, saturation with the binder in the upper layers of the protective crust and, accordingly, the required stability of the protective crust can be achieved with a lower specific binder consumption. Reducing the speed of impregnation as a result of pre-saturation of the upper layers of sand fixed by water can reduce the concentration of the binder in its working composition, which leads to a decrease in the cost of the product - a protective peel.

The study of the dependence of plastic strength on the concentration of the binder and the specific consumption of its working composition, when the required plastic strength $\mathrm{P}_{\mathrm{m}}$ $\geq(2.5-2.7) \mathrm{kPa}$ is reached, made it possible to determine the optimal concentration of the binder in solution: for dextrin -
$2.2 \%$, for glue KP-001 - 1.5\% (Figure 3). The characteristics of knitting-sandy crusts obtained by impregnating dry sand and sand with humidity $\mathrm{W}=20 \%$ within the specific consumption of the working composition of the binder from 3 to $5 \mathrm{l} / \mathrm{m} 2$ showed that the thickness of the crusts is $2-4$ times more, which also allows us to state the need for preliminary wetting the sand before consolidation, as well as the possibility of further reducing the specific consumption of the working composition of the binder and, in general, the possibility of saving resources.

$$
\begin{aligned}
& h=1.94 * q-1,04 \ldots . \\
& P_{m}=1.71 * q-0.52 \ldots .(3) \\
& \text { - on sand with humidity } \mathrm{W}=20 \% \text { : } \\
& h=0,17+3 * q \ldots(4) \\
& P_{m}=1,17+q \ldots(5)
\end{aligned}
$$




\section{Civil Engineering Research Journal}

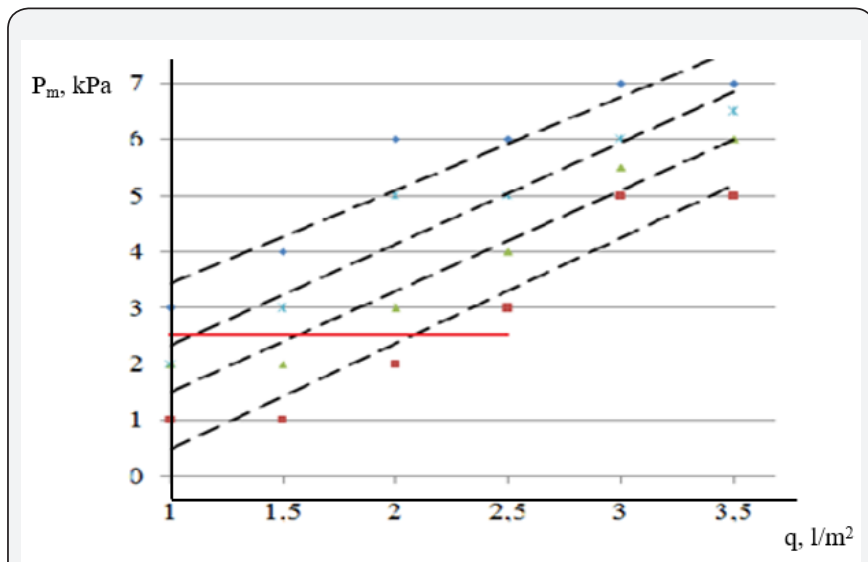

Figure 3: The dependence of plastic strength $P_{m}$ on the flow $q$ and concentration C KP-001 glue solutions (air-dry sand).

$1,2,3,4$ - protective crusts, obtained respectively from $1.5 ; 2,5,8 \%$ of KP-001 glue solutions; 5 -the line of maximum required value of plastic strength.

And also, the same dependencies were obtained from the specific consumption of the most economical concentration of the KP-0011.5 glue solution- on dry sand:

$$
\begin{aligned}
& h=2 * q-1 \ldots(6) \\
& P_{m}=1,88^{*} q-1,41 \ldots(7) \\
& \text { - on sand with humidity } \mathrm{W} \\
& h=0,5+3 * q \ldots(8) \\
& P_{m}=0,83+3 * q \ldots(9)
\end{aligned}
$$$$
\text { - on sand with humidity } \mathrm{W}=20 \% \text { : }
$$

It was found that on wet sand a crust with desired properties is obtained with a lower consumption of binder, this is apparently due to the nature of its distribution in depth and depends on the rate of impregnation (Table 4).

Table 4: Construction and technological characteristics of the protective crust.

\begin{tabular}{|c|c|c|c|c|c|c|}
\hline \multirow{2}{*}{$\begin{array}{c}\text { Binding on the } \\
\text { Basis of: }\end{array}$} & \multicolumn{5}{|c|}{$h(\mathrm{~mm}), \boldsymbol{P}_{\boldsymbol{m}}\left(\operatorname{Pa} \times 1^{3}\right), \boldsymbol{q}\left(\mathrm{l} / \mathrm{m}^{2}\right)$} \\
\cline { 2 - 7 } On Dry Sand & \multicolumn{3}{c|}{ On Wet Sand, W, \% } \\
\cline { 2 - 7 } & $\boldsymbol{h}$ & $\boldsymbol{P}_{\boldsymbol{m}}$ & $\boldsymbol{q}$ & $\boldsymbol{h}$ & $\boldsymbol{P}_{\boldsymbol{m}}$ & $\boldsymbol{q}$ \\
\hline dextrin & 5 & $4-4,5$ & 3 & 5 & $2,7-3$ & 1,5 \\
\hline \multirow{2}{*}{ polymer adhesive } & 5 & $4,2-4,5$ & 3,2 & 5 & $3-5$ & 1,5 \\
\hline
\end{tabular}

At the end, a whole series of physicochemical studies were carried out aimed at identifying the features of the structure formation of the binder-sanding materials of protective crusts. An X-ray diffraction analysis of the material of crusts was performed on an Empyreen diffractometer. Roentgenograms showed the absence of chemisorption bonds, which indicates that the structure of the astringent sand-protective layer is formed under the influence of the phenomenon of physical adsorption of the astringent, sticking grain of sand. In addition, it was found that aqueous solutions of glue and dextrin mainly interact with the phases "MicroMouse" (Microcline) and "Feldspar" (Albite). In the case of wet sand, this process occurs even before the binder is impregnated. Upon impregnation of wet sand with an astringent, the aforementioned interaction is likely to be completed - the layers of micro-mica are filled with moisture. Consequently, this explains the lower consumption of the binder and an increase in the depth of its impregnation with meeting the requirements for the stability of the protective crust.

On radiographs of materials obtained on wet sand, it is clear that peaks characteristic of water and polymer are several times smaller than similar peaks on radiographs of materials obtained on dry sand. This is probably due to the fact that with increasing colloidal layers of water adsorbed on the surface of sand particles, the pore space decreases. In this case, the size of the channels through which the binder penetrates into the sand decreases to sizes smaller than $\llbracket 10^{\wedge}(-2) \mathrm{mm}$, which as a result leads to a change in the predominantly gravitational nature of the impregnation to capillary. Impregnation of the wet substrate increases the saturation of the wetting phase, and this causes a deeper penetration of the solution into the wet sand. Studies have shown that the rate of impregnation in wet sand is lower compared to impregnation in dry sand, which leads to a deeper adsorption of the binder in the upper layer of the protective peel (Table 5).

Table 5: Recommended concentrations and unit costs of solutions.

\begin{tabular}{|c|c|c|c|}
\hline \multirow{2}{*}{$\begin{array}{c}\text { Type of } \\
\text { Binder }\end{array}$} & Concentration, \% & \multicolumn{2}{|c|}{$\begin{array}{c}\text { Specific Consumption of } \\
\text { Binders, } \mathbf{q}, \mathbf{1} / \mathbf{m}^{\mathbf{2}}\end{array}$} \\
\cline { 3 - 4 } & On Dry Sand & On Wet Sand \\
\hline $\begin{array}{c}\text { Dextrin solu- } \\
\text { tion }\end{array}$ & 2,2 & $3,2-3,5$ & 1,5 \\
\hline $\begin{array}{c}\text { KP-001 glue } \\
\text { solution }\end{array}$ & 1,5 & $3,0-3,3$ & 1,5 \\
\hline
\end{tabular}

The study of the structure of astringent crusts was carried out using IR spectroscopy. Impregnation of the wet substrate has been found to increase the saturation of the wetting phase, and this is the cause of the deeper penetration of the solution into the wet sand. Thus, the results of diffractometry and spectroscopy completely confirmed the correctness of the working hypothesis about the possibility of obtaining protective crusts of given properties when improving the technology of sand-binding and significant savings of resources (Table 6). 
Table 6: The dependence of the depth of impregnation of solutions from time (specific consumption of the working composition of binders on dry sand $3.0 \mathrm{l} / \mathrm{m}^{2}$ ).

\begin{tabular}{|c|c|c|c|}
\hline \multirow{2}{*}{$\begin{array}{l}\text { Impregnation } \\
\text { Methods }\end{array}$} & \multirow{2}{*}{$\begin{array}{c}\text { Time from } \\
\text { the Start of } \\
\text { Impregnation, } \\
\text { c }\end{array}$} & \multicolumn{2}{|c|}{$\begin{array}{l}\text { The Depth of the Layer from } \\
\text { the Surface of the Crust, } \mathrm{mm}\end{array}$} \\
\hline & & Dextrin & Glue KP-001 \\
\hline \multirow{5}{*}{$\begin{array}{c}\text { On air-dry } \\
\text { sand (3-5 \%) }\end{array}$} & 0 & 0 & 0 \\
\hline & 1 & 6 & 7 \\
\hline & 2 & 10 & 12 \\
\hline & 3 & 11 & 11 \\
\hline & 4 & 11 & 11 \\
\hline \multirow{7}{*}{$\begin{array}{l}\text { On wet sand } \\
\qquad(20 \%)\end{array}$} & 0 & 0 & 0 \\
\hline & 60 & 6 & 7 \\
\hline & 120 & 9 & 10 \\
\hline & 180 & 12 & 13 \\
\hline & 300 & 15 & 15 \\
\hline & 420 & 20 & 20 \\
\hline & 480 & 20 & 20 \\
\hline
\end{tabular}

The prices for April 2018 made a comparison of six methods of sand fixing, which became more widespread. Compared with the gossypol resin emulsion-based method, which is the most economical of all known, the savings per hectare when using dextrin solution will be 1,225 thousand soums, and when using a binder solution based on polymer glue - 1,575,000 soums. Compared to reed cells used in Uzbekistan, the savings per hectare using dextrin solution will be 5646 thousand soums and using polymeric glue solution - 5996 thousand soums. Production implementation of research results during 2015-2016. on sandystretched sections of the Navoi-Uchkuduk-Misken railway line, JSC Uzbekistan Railways fully confirmed the effectiveness of the use of the developed compositions and improved technology for fixing mobile sands. The result was: reduction of labor costs by $60 \%$ due to simplification and comprehensive mechanization of work; saving materials by $50 \%$ by reducing the specific consumption of the working composition of the binder and strip processing; increase in seed germination of sand-loving plants (phytomelioration) by $15 \%$.

\section{Conclusion}

A. Developed new complex resource-saving methods of obtaining a protective crust by impregnating moving sands of dry and wet conditions with working compositions of binding substances based on dextrin and KP-001 glue:

a) dextrin - 2.2\%; $\mathrm{NaOH}-0.4 \%$; HS (plasticizer) - $0.6 \%$; water $-96.8 \%$.

b) KP - 001 glue - 1.5\%; water - 98.5, providing the required stability of the astringent sand protective cover to the wind-sandy stream.

B. A rapid method for the study of resource-saving assessment of the possibility of using binders to create protective crusts is proposed. $\mathrm{kPa}$ respectively on horizontal and sloping sandy surfaces.

C. A method has been developed for estimating the wind resistance of a knitted sand crust by physical modeling in a wind tunnel.

D. The role of sand moisture as a resource-saving factor in obtaining a protective crust resistant to wind-sand flow, which significantly changes the character of impregnation from mainly gravitational to capillary as a result of pore space narrowing, which sharply reduces the impregnation rate and, as a result, leads, ultimately, to a significant decrease in the concentration of the binder in the solution and its specific consumption.

E. New technological solutions made it possible to reduce labor costs by $60 \%$, to obtain a reduction in the consumption of binders by $50 \%$, to increase seed germination of sandloving plants by $15 \%$.

F. Pilot production of the research results confirmed the hypotheses put forward.

\section{References}

1. Babaev AG, Zonn IS, Drozdov NN, Freykin ZG (1895) Blanc, Edouard. Le chemin de fer transcaspien. Annales de Géographie 4(16) : 325-345.

2. Flock A (1929) Le chemin de fer transsaharien: tracé, construction, exploitation. Paris : Société d'éditions géographiques, maritimes et coloniales, p. 188.

3. (2016) Etihad Rail - the first railway of the UAE / Railways of the World.

4. Ashkenazy Y, Yizhaq H, Tsoar H (2012) Sandhill and Australian deserts. Climatic Change 112 (3-4) : 901-923.

5. Hagdorn M, Busche D, Draga M (1985) Les sables éoliens, modelés et dinamique La menace éolienne et son contrŏle. Bibliographie annotée, Deutsche, GesTechnZusammenarbeit (GTZ), Schiftereibe, p. 758.

6. Petrov MP (1989) Affroestation and sand-stabilization of mobile sands in the world.

7. Sourel MF (1985) Etude de l'evolution récente des milieu sahéliens á hartir des measures fournies par les satellites. Paris, IBM, p. 405.

8. Khalaf FI, Al-Ajmi D (1993) Aeolian processes and sand encroachment problems in Kuwait. Kuwait Institute for Scientific Research Geomorphology 6(2): 111-134.

9. Mainquet M (1996) Aridité, sécheresse et dégradationdans les aires sèches de Chine. Secheresse 7: 41-50.

10. Cheng J, Jiang F, Yang Y, Xue C (2003) College of Water Resources and Architectural Engineering. Shihezi University, Shihezi Xinjiang, China.

11. (2017) EU: Seek Stronger Central Asia Rights Commitments.

12. Babaev AG (1986) Principles and methods of fixing moving sands.

13. Lepesko VV (2016) Fastening of mobile sands with shrubs and grasses with the use of bonding agents in the Astrakhan Trans-Volga region.

14. Aiban SA (1994) A study of sand stabilization in eastern Saudi Arabia. Engineering Geology 38(1-2): 65-79.

15. Busche D, Draga M, Hagdorn M (1984) Les sables éoliens, modelés et dynamique, p. 758. 


\section{Civil Engineering Research Journal}

16. Rochette RM (1989) Le Sahel en lute contre la désertification; leçonsd'expériences. p. 592.

17. Rehman Sach (1999) Stabilization des dunes de sable dans la vallée de Mastung (Baluchistan, Pakistan). Sécheresse6(4): 347-354.

18. Zakirov RS, Omarov AD (2002) Fastening the slopes of the roadbed and the adjacent strip of sand in arid regions.

19. Palagashvili VM (1974) The use of bitumen emulsions when fixing moving sands.

20. Podgornov AS (1980) Fastening of mobile sands with binders.

21. Adilhojaev AI (1978) Binder for fixing shifting sands.

22. Azizov A, Atabaev B (1989) Investigation of the effect of wind-sand flow on the erosion resistance of soils superficially treated with various anti-erosion preparations.
23. Mirakhmedov MM, Muzaffarova MK (2016) Perspectives fixation drift sands physicochemical method Transport problems 11(3) 143-152.

24. Muzaffarowa MK, Mirakhmedov MM (2014) Differences of air-dry and wet sand. Transport problems. 9(3): 91-97.

25. Mirakhmedov M, Muzaffarova MK, Mamadaliev AY (2017) Resourcesaving technologies to reduce the negative impact of manifestations of exogenous processes on the railway.

26. Mirakhmedov MM, Muzaffarova M (2015) Methodological aspects of the development of resource-seving tcchnologies of shifting sands fixation.

27. Fazilov TI (1991) Organic-mineral anti-deflationary coatings obtained by impregnation of mobile sands.

\section{Your next submission with Juniper Publishers will reach you the below assets}

- Quality Editorial service

- Swift Peer Review

- Reprints availability

- E-prints Service

- Manuscript Podcast for convenient understanding

- Global attainment for your research

- Manuscript accessibility in different formats

( Pdf, E-pub, Full Text, Audio)

- Unceasing customer service

Track the below URL for one-step submission https://juniperpublishers.com/online-submission.php 